\title{
Phenolics profile and anti-proliferative activity of Cyphomandra Betacea fruit in breast and liver cancer cells
}

\author{
Maisarah Abdul Mutalib ${ }^{1}$, Faisal Ali ${ }^{1,2}$, Fauziah Othman ${ }^{3}$, Rajesh Ramasamy ${ }^{4}$ and Asmah Rahmat ${ }^{1 *}$
}

\author{
*Correspondence: \\ Profasmah@gmail.com \\ ${ }^{1}$ Department of Nutrition \\ and Dietetics, Faculty \\ of Medicine and Health \\ Sciences, Universiti \\ Putra Malaysia (UPM), \\ 43400 Serdang, Selangor, \\ Malaysia \\ Full list of author information \\ is available at the end of the \\ article
}

\begin{abstract}
Background: Cyphomandra betacea (C. betacea) belongs to the Solanaceae family. This study was aimed to evaluate the anti-proliferative of C.betacea crude extract against selected cancer cell lines (breast and liver cancer) and to identify the polyphenolics profile (phenolic acids and flavonoids) of $C$. betacea fruits. Anti-proliferative effect of the extracts was examined using MTT (3-(4,5-dimethylthiazol-2yl)-2,5-diphenyltetrazolium bromide) assay, followed by cell morphology analysis using acridine orange and propidium iodide double staining.
\end{abstract}

Results: The phenolics profile was characterized using high-performance liquid chromatography (HPLC). C. betacea extract showed a high cytotoxic effect against liver and breast cancer cell lines with the $\mathrm{IC}_{50}$ value of 30 and $80 \mathrm{\mu g} / \mathrm{ml}$, respectively. Phenolics profiling showed that $C$. betacea extract has a wide variety of polyphenolic compounds which are the responsible substances underlying the cytotoxic activity. The microscopic examination analysed by acridine orange and propidium iodide double staining showed that viable cells of the liver and breast cells were well rounded, large and intact green nuclei compared with the treated cells that characterized by apoptotic features (shrunken nuclei with a less quantity of cytoplasm).

Conclusion: The present study demonstrated that the anti-proliferative properties of C. betacea fruits were partially attributed to the rich phenolics content. It supports the hypothesis that $C$. betacea fruits have potential as an effective agent in cancer therapy.

Keywords: Anti-proliferative activity, Cyphomandra betacea, Breast cancer cell, Liver cancer cell, Phenolics

\section{Background}

It is known that some of the medicinal plants possess anticancer activity. In addition, polyphenols from fruits or vegetables are the responsible molecules for the chemopreventive effects. Epidemiological studies have shown that high dietary intake of polyphenols from plant is associated with a decreased risk of the degenerative diseases, including cardiovascular diseases and certain cancers (Kumar and Pandey 2013). The major dietary polyphenols are flavonoids and the most anticancer compounds of which are catechins, curcumin, resveratrol and genistein (Dai and Mumper 2010). The process of carcinogenesis includes 3 important stages; initiation, promotion and progression (Wattenberg 1985). These phenolics substances have been shown to hinder cancer 
progression by interfering with each of the stage of carcinogenesis. Several studies have proposed that the anticancer ability of some dietary polyphenols such as quercetin, genistein, apigenin was depending on the inhibition of the proliferation process of various cancers in vitro and in vivo (Fantini et al. 2015).

Phenolic acids are non-flavonoid polyphenolic compounds that are often in bound form which are abundant in fruits, vegetables, grains and seeds (Tsao 2010). They are commonly represented by vanillic acid, $p$-coumaric acid, caffeic acid, ferulic acid and gallic acid. Caffeic acid has been reported to suppress the activation of NF-kB and AP1 which might contribute to their chemopreventive effects (Bharti and Aggarwal 2002). Flavonoids are further divided into several classes which include flavones, flavanones, isoflavones, anthocyanins, flavonols, and flavanols. Moreover, the Isoflavones such as genistein and daidzein that are known for their estrogenic activity have shown a putative role in the prevention of breast cancer (Barnes 2003).

The subtropical fruit C. betacea belongs to the Solanaceae family (Lim 2013). Commonly known as tamarillo, tree tomato or 'buah cinta' among the locals. C. betacea is considered as an undervalue fruit in Malaysia, which is grown in Cameron Highland (Peninsular Malaysia) and Kundasang (Sabah). Several of underutilized fruits are reported to be rich in bioactive compounds which make them good potential sources for the production of neutraceuticals, flavors and pharmaceuticals (Ali Hassan and Abu Bakar 2013). However, these types of fruits are often underutilized due to their unidentified features, and economical prospective. Hence, these underutilized fruits provide unlimited opportunities for using as a potential phytomedicine as they are known to possess an array of chemical diversity, which needs to be investigated. There is a limited knowledge about the phytochemical profiles, antioxidant and anticancer potential of $C$. betacea. Hence the present study has been aimed to understand the antioxidant activities and antiproliferative effects of $C$. betacea. It has been reported that $C$. betacea is rich in $\beta$-carotene and ascorbic acid which makes them good natural sources of provitamin A and vitamin $C$. The fruits also having rich contents of anthocyanin and carotenoids which are responsible for their colour due to its natural pigments and both demonstrate the important biological, therapeutic, and preventative properties (de Rosso and Mercadante 2007).

Previous study reported that $C$. betacea displayed higher antioxidant properties than Lycopersicon esculentum (cherry tomato) and Solanum lycopersicum (tomato). The total phenolic content of C. betacea was $7.63 \mathrm{mg}$ gallic acid equivalent/g (Noor Atiqah et al. 2014). Various research groups have screened a variety of fruit for their antioxidant activity but none appear to have included C. betacea. Thus, in the present study we aimed to determine the antiproliferative activity of $C$. betacea fruits against breast and liver cancer lines and also to study the polyphenol distribution.

\section{Methods}

\section{Fruit sampling}

The fruits of C. betacea were collected from Cameron Highland, Pahang, Malaysia, during June 2013. The herbarium specimens were identified and deposited in BORNEENSIS, University Malaysia Sabah, Malaysia. The fruits were cleaned and weighed. The small cut pieces were freeze-dried, and ground into fine powder using a grinder. The 
ground samples were sieved to get uniform size and then kept in an air-tight container and stored in a freezer $\left(-20^{\circ} \mathrm{C}\right)$ until further analysis.

\section{Sample preparation}

Fine powders $(2.5 \mathrm{~g})$ were extracted with $50 \mathrm{ml} 80 \%$ ethanol. The dry residue $(50 \mathrm{mg})$ was dissolved in DMSO $(1 \mathrm{ml})$ to obtain working solution of $1 \mathrm{mg} / \mathrm{ml}$. These final extracts were filtered through a $0.45 \mu \mathrm{m}$ nylon membrane syringe filter before use.

\section{MTT (3-(4,5-dimethylthiazol-2yl)-2,5-diphenyltetrazolium bromide) assay}

The human tumour cell lines HepG2 (liver), MDA-MB-231(breast) and 3T3 (normal mouse fibroblast) cell lines were obtained from the American Type Culture Collection (ATCC, VA, USA). Cells were routinely grown with RPMI-1640 media supplemented with $10 \%$ fetal calf serum and $1 \%$ penicillin/streptomycin and incubated at $37{ }^{\circ} \mathrm{C}$ humidified atmosphere of $5 \% \mathrm{CO}_{2}$ in $\mathrm{T} 75\left(75 \mathrm{~cm}^{2}\right)$ flasks. The potential effects on cell viability were investigated using the MTT assay as an indicator of metabolically active cells. The cells were diluted in culture medium to a concentration of $1 \times 10^{5}$ cells $/ \mathrm{ml}$ and were pipetted into 96-well plates and incubated at $37{ }^{\circ} \mathrm{C}$ humidified, $5 \% \mathrm{CO}_{2}$ incubator atmosphere to attach for $24 \mathrm{~h}$. Cells were then exposed with $C$. betacea extracts $(6.25,12.5$, $25,50,100,200 \mu \mathrm{g} / \mathrm{ml}$ ) through twofold serial dilutions (Kaewpiboon et al. 2014). Cells were also treated with doxorubicin $(0.20,0.39,0.78,1.56,3.13,6.25,12.5,25 \mu \mathrm{g} / \mathrm{ml})$ that served as a positive control and culture medium (1\% DMSO) was used as a negative control. After $72 \mathrm{~h}$ of extracts and drug exposure, the culture medium was removed and $10 \mu \mathrm{l}$ of MTT reagent was added. Following incubation for $4 \mathrm{~h}$, the MTT/medium was removed and DMSO $(100 \mu \mathrm{l})$ was added to dissolve the formazan crystals. Absorbance of the colored solution was measured on an ELISA plate reader. Percentage of cytotoxicity was calculated as follows:

$$
\% \text { Cytotoxicity }=\frac{\text { OD sample }}{\text { OD negative control }} \times 100 \%
$$

All experiments were performed in triplicate. The concentration of substance required for $50 \%$ growth inhibition $\left(\mathrm{IC}_{50}\right)$ was estimated as that giving a $50 \%$ decrease in absorbance as compared to controls incubated simultaneously without substances.

\section{Determination of apoptosis by acridine orange/propidium iodide (AO/PI) staining}

HepG2 and MDA-MB-231 cancer cell lines were seeded into 6 well plate at a density of $1 \times 10^{5}$ cells $/ \mathrm{ml}$ and incubated for $24 \mathrm{~h}$ at $37{ }^{\circ} \mathrm{C}$ in $5 \% \mathrm{CO}_{2}$ incubator. After $24 \mathrm{~h}$, cells were treated with $C$. betacea extract $\left(\mathrm{IC}_{50}\right.$ values), doxorubicin $(8 \mu \mathrm{g} / \mathrm{ml})$ that served as positive control and culture medium (1\% DMSO) that served as negative control for 24, 48 and $72 \mathrm{~h}$. After exposure of grown cells in the extract, cells were washed with phosphate buffer saline (PBS) and harvested by centrifugation (2000 rpm for $5 \mathrm{~min}$ ) and washed twice with PBS. The pellet $(10 \mu \mathrm{l})$ were mixed with $5 \mu \mathrm{l}(10 \mu \mathrm{g} / \mathrm{ml})$ acridine orange and $5 \mu \mathrm{l}(10 \mu \mathrm{g} / \mathrm{ml}) \mathrm{PI}$ and observed under fluorescence microscope (Ekowati et al. 2010). 


\section{DNA ladder assay}

Fragmentation of chromatin DNA is one of the hallmarks of apoptosis. The quality of DNA was obtained with DNA laddering kit following manufacturer's instructions Cayman Chemical (MI, USA). HepG2 and MDA-MB-231 $\left(1 \times 10^{5}\right.$ cells $\left./ \mathrm{ml}\right)$ cancer cells were seeded into 6-well plate and incubated for $24 \mathrm{~h}$. After $24 \mathrm{~h}$, HepG2 and MDA-MB-231 cells were treated with 30 and $80 \mu \mathrm{g} / \mathrm{ml}$ of C. betacea extracts, doxorubicin $(8 \mu \mathrm{g} / \mathrm{ml})$ and culture medium (1\% DMSO) that served as negative control. After $72 \mathrm{~h}$ exposure of grown cells in the extract, cells were washed with phosphate buffer saline (PBS) and harvested by centrifugation at $2000 \mathrm{rpm}$ for $5 \mathrm{~min}$ at room temperature $\left(25^{\circ} \mathrm{C}\right)$. The supernatant was discarded and pellet $\left(1 \times 10^{5}\right.$ cells $)$ in $200 \mu \mathrm{l}$ of samples volume was mixed with $100 \mu \mathrm{l}$ of Lysis Buffer and vortexed for $10 \mathrm{~s}$. Then, the mixture was centrifuged at $8000 \mathrm{rpm}$ for $1 \mathrm{~min}$ at room temperature. The supernatant was collected and mixed with $20 \mu \mathrm{l}$ of $10 \%$ SDS for each sample and vortexed again before added $20 \mu \mathrm{l}$ of Enzyme A. Samples were vortexed and incubated at $56^{\circ} \mathrm{C}$ for $1 \mathrm{~h}$. Then, $20 \mu \mathrm{l}$ of Enzyme B was added to each sample and incubated at $37^{\circ} \mathrm{C}$ for another $1 \mathrm{~h}$. Precipitating reagent $(130 \mu \mathrm{l})$ and ice-cold ethanol $(950 \mu \mathrm{l})$ were then added to each tube. Samples were vortexed and centrifuged at $12,000 \mathrm{~g}$ for $5 \mathrm{~min}$ at $4{ }^{\circ} \mathrm{C}$. After centrifugation, supernatant was discarded and pellet was washed once with ice-cold $80 \%$ ethanol. Pellets were then dried on the bench for $5-10 \mathrm{~min}$. TE buffer $(100 \mu \mathrm{l})$ was added in each sample by vigorous vortexing. Samples $(15 \mu \mathrm{l})$ were mixed with $3 \mu \mathrm{l}$ of Gel-Loading Buffer $(6 \times)$ and electrophoresed on a $1 \%$ agarose gel pre-stained with ethidium bromide at $75 \mathrm{~V}$ for $60 \mathrm{~min}$. The fragmented inter-nucleosomal DNA was visualized using FluorChem 5500 Chemiluminescent (Alpha Innotech, CA, USA).

\section{Determination of polyphenol by HPLC}

HPLC apparatus: The polyphenolic composition of the $C$. betacea fruits were determined by using HPLC-DAD (Agilent 1100, CA, USA). A reversed-phase C18 column (Nova-Pak, $150 \mathrm{~mm} \times 4 \mathrm{~mm}, 5 \mu \mathrm{m}$ ) from Waters (MA, USA) was used throughout this study. All reagents were obtained from Merck (Darmstadt, Germany) HPLC grade. The prepared mobile phase was degassed using ultrasonic agitation and filtered under vacuum through a $0.45 \mu \mathrm{m}$ nylon membrane filter before analysis. The rate flow was set at $1 \mathrm{ml} / \mathrm{min}$. The operating temperature was maintained at room temperature $\left(25^{\circ} \mathrm{C}\right)$.

Analysis of phenolic acids and flavonoids: The polyphenolic composition of the $C$. betacea fruits was determined according to method as described by Uddin et al. (2014) with slight modification. Samples $(1 \mathrm{~g})$ were mixed with $4 \mathrm{ml}$ of $80 \%$ ethanol for $24 \mathrm{~h}$. The mixture was later centrifuged $(5000 \mathrm{rpm}$ for $15 \mathrm{~min})$ at room temperature $\left(25^{\circ} \mathrm{C}\right)$. The supernatant was filtered through $0.45 \mu \mathrm{m}$ nylon membrane filter prior use. The mobile phase was composed of (A) 0.5\% acetic acid, and (B) methanol, and the gradient elution was performed as follows: $0 \mathrm{~min}, 100: 0 ; 20 \mathrm{~min}, 10: 90$; and $30 \mathrm{~min}, 100: 0$ and filtered under vacuum through $0.45 \mu \mathrm{m}$ membrane filter before use. The detection and quantification of gallic acid and caffeic acid was done at $254 \mathrm{~nm}$, chlorogenic acid, epigallocatechin gallate, vanillic acid, p-coumaric acid and naringin was done at $280 \mathrm{~nm}$, trans-ferullic acid and ferullic acid at $329 \mathrm{~nm}$ while quercetin and kaempferol were detected at $370 \mathrm{~nm}$. 
Standards: All standards were dissolved in $80 \%$ ethanol and prepared between the range of 20 and $100 \mu \mathrm{g} / \mathrm{ml}$. All standards used were of the highest purity (HPLC grade) were obtained from Sigma (Darmstadt, St. Louis), were filtered through $0.45 \mu \mathrm{m}$ nylon membrane syringe filter before injections.

\section{Statistical analysis}

Data are presented as mean \pm S.E.M and all experiments were carried out with three replicates. The data was statistically analysed using SPSS version 21.0. One-way analysis of variance (ANOVA) with Tukey's test was used to test for differences between multiple groups. Level of significance was set at $p \leq 0.05$. Independent-Samples $T$ Test was used to test for significant differences in phenolic compounds of both extracts which was considered at the level of $p \leq 0.05$.

\section{Results and discussions}

\section{Cytotoxicity activity}

The cytotoxic behaviour of $C$. betacea fruits were tested in two different human cancer cell lines: liver (HepG2) and mammary gland (MDA-MB-231) adenocarcinoma. The experiments were also carried out in normal mouse fibroblast (3T3) to investigate its toxicity towards normal cells. The endpoint criteria for antiproliferative activity was selected according to the cytotoxic activity of $\mathrm{IC}_{50}$ values that should be below $100 \mu \mathrm{g} /$ $\mathrm{ml}$ for crude extracts and less than $25 \mu \mathrm{M}$ for pure compounds (Cos et al. 2006). Figure 1a shows that $C$. betacea extract strongly inhibited the proliferation of HepG2 and MDA-MB-231 cell lines in a dose-dependent manner with $\mathrm{IC}_{50}$ values of 30 and $80 \mu \mathrm{g} /$ $\mathrm{ml}$, respectively. It was verified that the increased in concentration of $C$. betacea fruits leads to a higher cytotoxic activities. However all the sample extracts did not exert any significant cytotoxic effect against $3 \mathrm{~T} 3$ cell $\left(\mathrm{IC}_{50}>200.00 \mu \mathrm{g} / \mathrm{ml}\right)$. Doxorubicin (chemotherapy drug) was capable to induce cytotoxicity in HepG2 and MDA-MB-231 with $\mathrm{IC}_{50}$ value of 0.35 and $0.78 \mu \mathrm{g} / \mathrm{ml}$ respectively, as shown in Fig. 1b. Nevertheless, results also proved that doxorubicin showed superior cytotoxic activity against 3T3 normal cell with $\mathrm{IC}_{50}$ value of $8 \mu \mathrm{g} / \mathrm{ml}$ (Fig. 1b).

Previous study reported that the cancer preventing action of fruits and vegetables is most probably due to the several bioactive compounds that act simultaneously to prevent cancer rather than being one or two potent anticarcinogens (Tomás-Barberán and Gil 2008). As chemopreventive agents, phytochemicals can interfere in different step of carcinogenesis (promotion, initiation and progression) by two major actions; cancer blocking agents and cancer suppressing agent (Surh 2003). Some chemopreventive phytochemicals inhibit the metabolic action of the pre-carcinogens, consequently block the tumor initiation.

\section{$\mathrm{AO} / \mathrm{PI}$ double staining and fluorescent microscopy}

Staining cells with fluorescent dyes is useful in evaluating the nuclei morphology of apoptotic cells and mode of cell death. Apoptotic and viable cells of HepG2 and MDAMB-231 were evaluated using fluorescent microscope. Healthy viable cells of HepG2 and MDA-MB-231 were visualized well rounded, large and intact green nuclear structure (Figs. 2a, 3a) while observations of cells treated with C. betacea extract based on their 

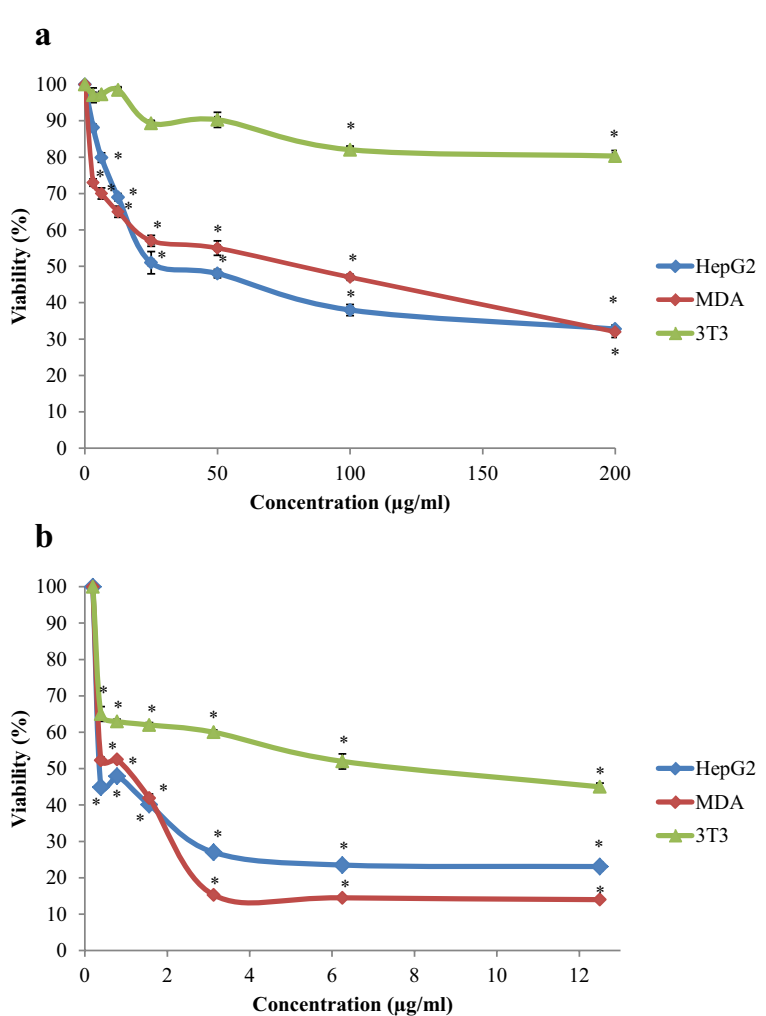

Fig. 1 Cytotoxic effects of C. betacea (a) and doxorubicin (b) on HepG2 and MDA- and $3 T 3$ cell lines viability, assessed by MTT assay. Values are presented as means $(n=3) \pm S D$, and ${ }^{*} p<0.05$ compared to negative control

$\mathrm{IC}_{50}$ values were identified shrinking with condensed fragmented nuclei that confirmed apoptosis in a time dependent manner (Figs. 2b-d, 3b-d). Early apoptosis features (Figs. 2e, 3e) were seen for HepG2 and MDA-MB-231 treated with 0.35 and $0.78 \mu \mathrm{g} /$ $\mathrm{ml}$ of Doxorubicin, respectively. AO penetrated within the fragmented DNA (FN) and displayed nuclear condensation that indicates moderate apoptosis. Late stage of apoptosis (LA) showed the presence of apoptotic bodies (AB) observed as orange-red fluorescence represents the hallmark of late apoptosis (Figs. 2b-d, 3c, d). In addition, cells were noticeable with asymmetrically localized, membrane blebbing (BL) and nuclear margination (CC) as can be seen in Figs. 2b-e and 3b-e for HepG2 and MDA-MB-231, respectively.

\section{DNA laddering}

Detection of DNA fragmentation become a widely accepted biochemical hallmark of apoptotic cytotoxicity and drug induced apoptosis in cancer cells (Kroemer et al. 1995). Figure 4 shows the DNA fragmentation which was detected in HepG2 (lane b and c) and MDA-MB-231 (Lane D and E) cancer cell lines treated with C. betacea extract based on their $\mathrm{IC}_{50}$ and $\mathrm{IC}_{75}$ values after $72 \mathrm{~h}$ incubation. However, there is no DNA 

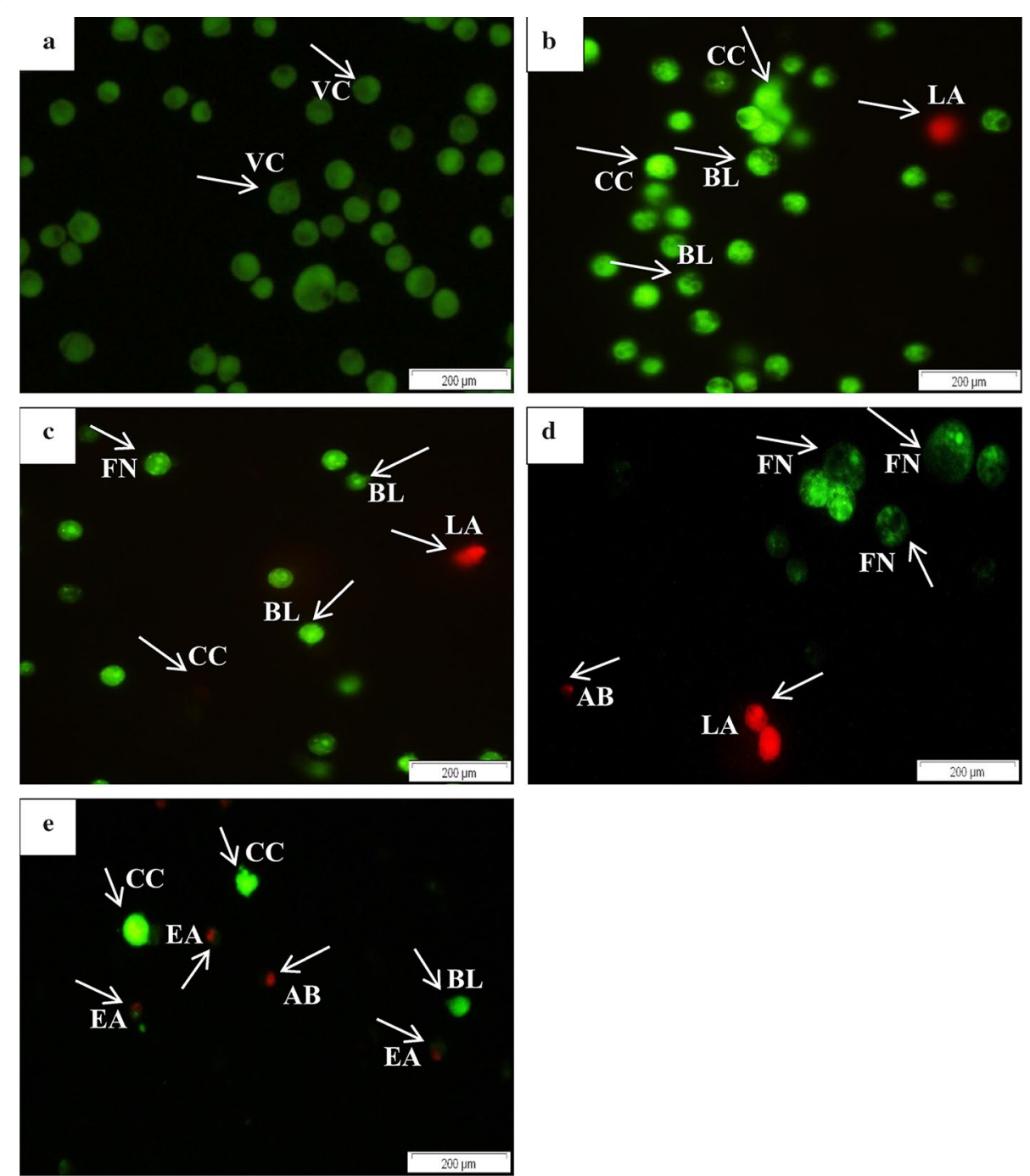

Fig. 2 Fluorescent micrographs of AO/PI double stained of HepG2 cells treated with C. betacea at $30 \mu \mathrm{g} / \mathrm{ml}$ for 24, 48 and 72 h. a Untreated HepG2 cells showing normal cell structure and viable cells fluoresce green with round intact nuclei. b After $24 \mathrm{~h}$ treated group showing chromatin condensation, membrane blebbing and late apoptosis. c Chromatin condensation, membrane blebbing, DNA fragmentation and late apoptosis events were observed after $48 \mathrm{~h}$ of treatment. d Apoptotic body formation after $72 \mathrm{~h}$ of treatment. e HepG2 cell treated with $8 \mu \mathrm{g} / \mathrm{ml}$ of doxorubicin showed early apoptosis event and formation of apoptotic body. Scale bars (A-E): $200 \mu \mathrm{m}$ (magnification: $\times 200$ ). VC Viable cells, BL Blebbing of cell membrane, CC Chromatin condensation, FN Fragmented nuclei, EA Early apoptosis, LA Late apoptosis, AB Apoptotic bodies

fragmentation was observed in control (untreated) cells as shown in Lane D and Lane G for HepG2 and MDA-MB-231 cells, respectively. Conversely, the standard doxorubicin induced the fragmentation of the DNA at very low concentration $(8 \mu \mathrm{g} / \mathrm{ml})$ as shown in Lane $\mathrm{H}$ and Lane I for HepG2 and MDA-MB-231 cells, respectively. These results indicate that cytotoxic activity is present in C. betacea and exerted substantial DNA damage leading to apoptotic cell death in HepG2 and MDA-MB-231 cancer cell lines. 

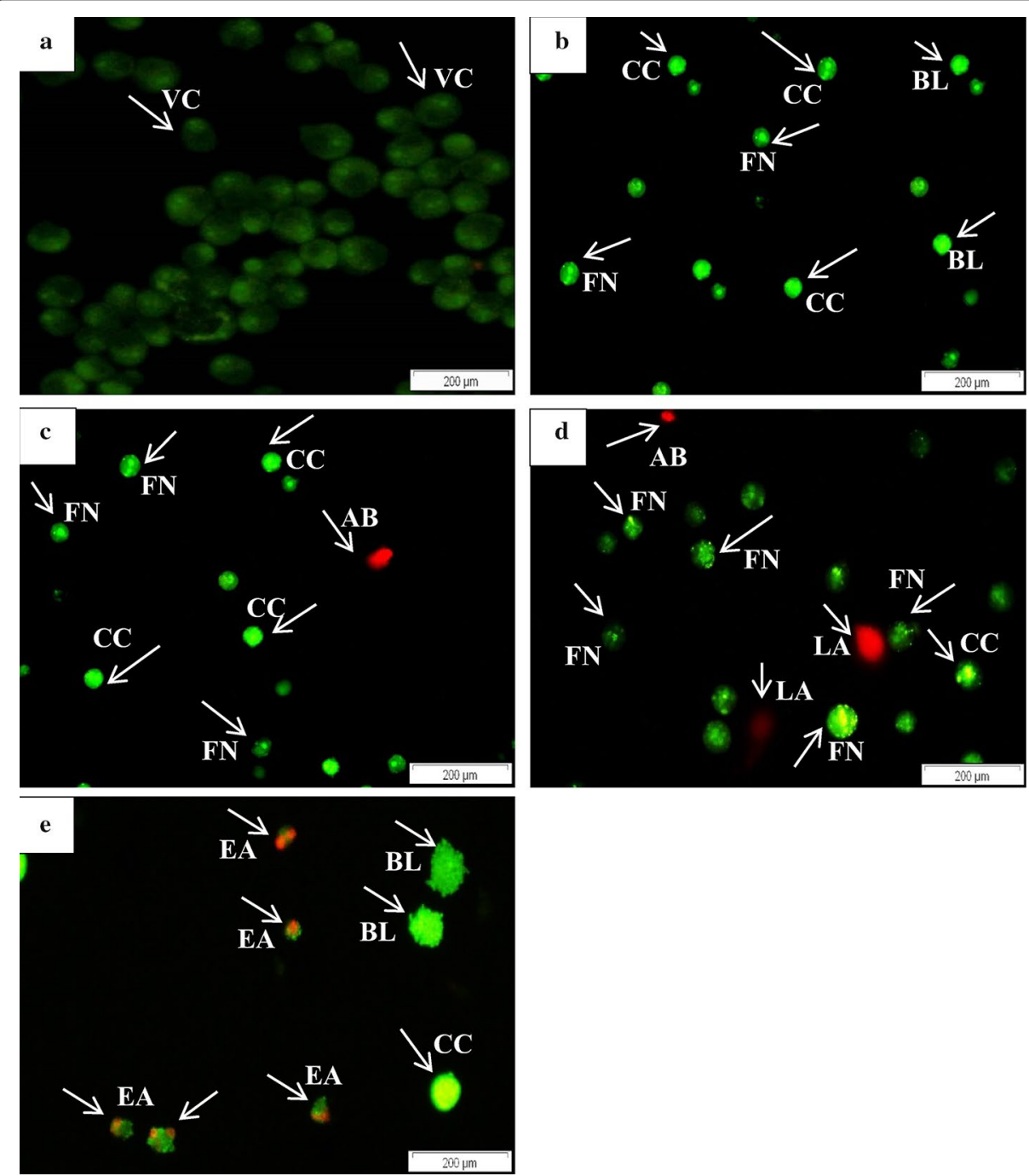

Fig. 3 Fluorescent micrographs of AO/PI double stained of MDA-MB-231 cells treated with C. betacea at $80 \mathrm{\mu g} / \mathrm{ml}$ for 24, 48 and $72 \mathrm{~h}$. a Untreated MDA-MB-231 cells showing the normal viable cells with circular nucleus uniformly distributed in the centre of the cell. $\mathbf{b}$ Blebbing or signs of membrane protrusions and fragmented of nuclei were evident after $24 \mathrm{~h}$ of treatment. Nucleus showed green fluorescence and concentrated into a granular that indicates chromatin condensation. $\mathbf{c} 48 \mathrm{~h}$ treated cells detected as rounding off, reduction in cell size, damaged membrane and appearance of apoptotic body. $\mathbf{d}$ Necrotic cells: $72 \mathrm{~h}$ treated cells showed late apoptosis events with formation of apoptotic body, unsymmetrical shape and size, uneven and disintegrated membrane surface. e MDA-MB-231 cell treated with $8 \mu \mathrm{g} / \mathrm{ml}$ of doxorubicin showed early apoptosis events with appearance of membrane blebbing and chromatin condensation. Scale bars (a-e): $200 \mu \mathrm{m}$ (magnification: $\times$ 200).VC Viable cells, BL Blebbing of cell membrane, CC Chromatin condensation, FN Fragmented nuclei, EA Early apoptosis, LA Late apoptosis, AB Apoptotic bodies

\section{Phytochemical compositions}

\section{Phenolic acids composition}

The major secondary metabolites in plants include terpenoids, alkaloids, sulphur-containing compounds and phenolic compounds (Dillard and Bruce 2000). The main phenolic subclass in fruits are phenolic acids (hydroxybenzoic and hydroxycinnamic acid), flavonoids, and coumarin (Hounsome et al. 2008). Phenolic acids in general are phenols 


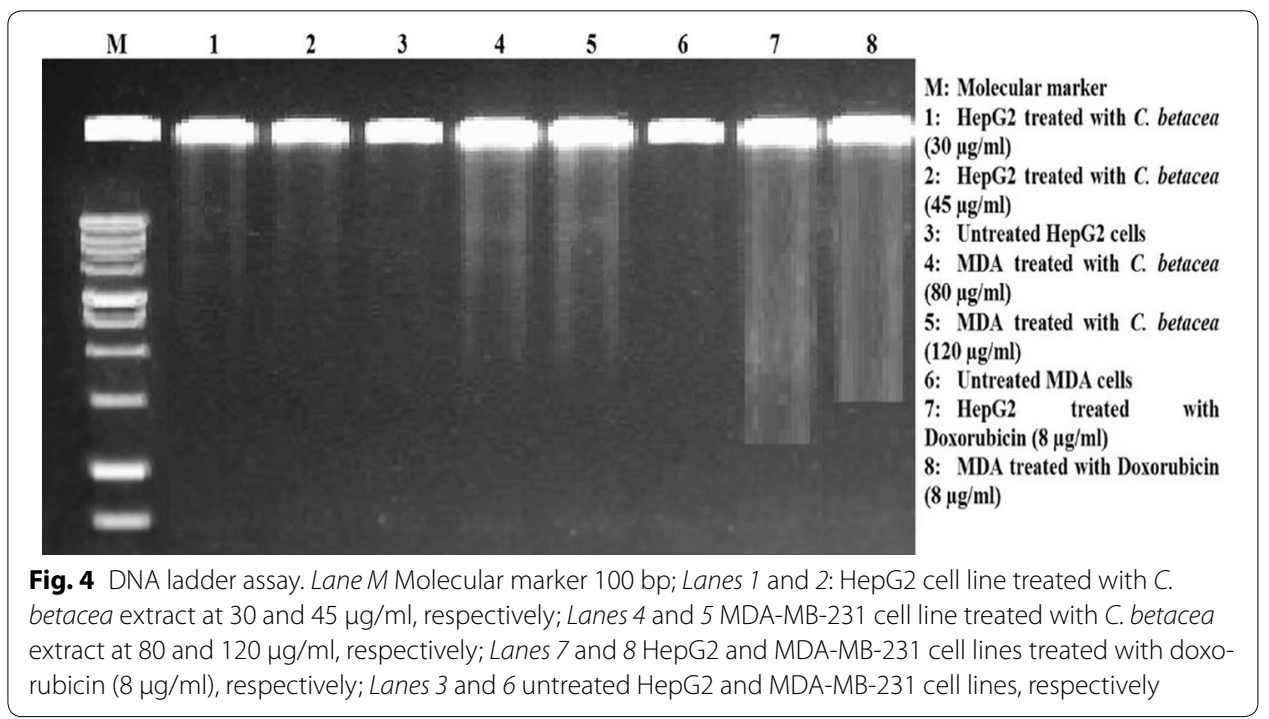

with one carboxylic acid group. Hydroxybenzoic acids (vanillic and gallic acid) have the carboxylic acid group directly attached to the ring, while hydroxycinnamic acids ( $p$-coumaric acid, caffeic acid, ferulic acid, trans-ferulic acid and chlorogenic acid) have a three-carbon side chain. Phenolic compounds have been reported to possess antioxidants, antibacterial, anticancer and anti-inflammatory properties (Ghasemzadeh et al. 2010).

Figure 5 illustrates the separation of flavonoids and phenolic acids in C. betacea extract, while Fig. 6 shows the mixture of 11 external standards for flavonoids and phenolic acids. A good separation was achieved in a short separation time of $26 \mathrm{~min}$. Phenolic acid contents achieved from C. betacea extract were presented in Table 1 . Out of seven phenolic acids tested, gallic, caffeic and vanillic acids were found to be most abundant in the samples tested. While ferulic, p-coumaric and trans-ferulic acids were found in minor quantity in the samples tested ranged from 0.05 to $0.49 \mu \mathrm{g} / \mathrm{g} \mathrm{DW}$. Caffeic and gallic acids display a wide variety of biological functions including their primary antioxidant activity, which are mainly related to the modulation of carcinogenesis. In addition, gallic acid has been proven to protect against oxidative damage induced by reactive oxygen species (ROS) and act as chemopreventive agents that cause apoptosis in the proliferation of several tumour cell lines. For an instance, Lim (2013) has reported that $C$. betacea prevented oxidative stress-induced cell death in HepG2 cells in a dosedependent manner.

The genus of Solanum (Solanaceae) can be an important source of natural antioxidants, particularly the phenolic acid compositions. Some of these phytochemicals include 2-methyl[1,3,4] oxadiazole, 2,3-dihydro-3,5-dihydroxy-6-methyl-4H-pyran-4-one and thiazole that may have the role in anti-inflammatory effects while $n$-hexadecanoic acid may be responsible in the antioxidant activities. The other compound identified was 1,3,4-Oxadiazole (OXD) products that are well-known for their anti-inflammatory, (Dr. Duke's phytochemical and ethnobotanical databases), antibacterial, antifungal activity (El-Emam et al. 2004) and HIV replication inhibition (Sahin et al. 2002). Furthermore, 
mAU
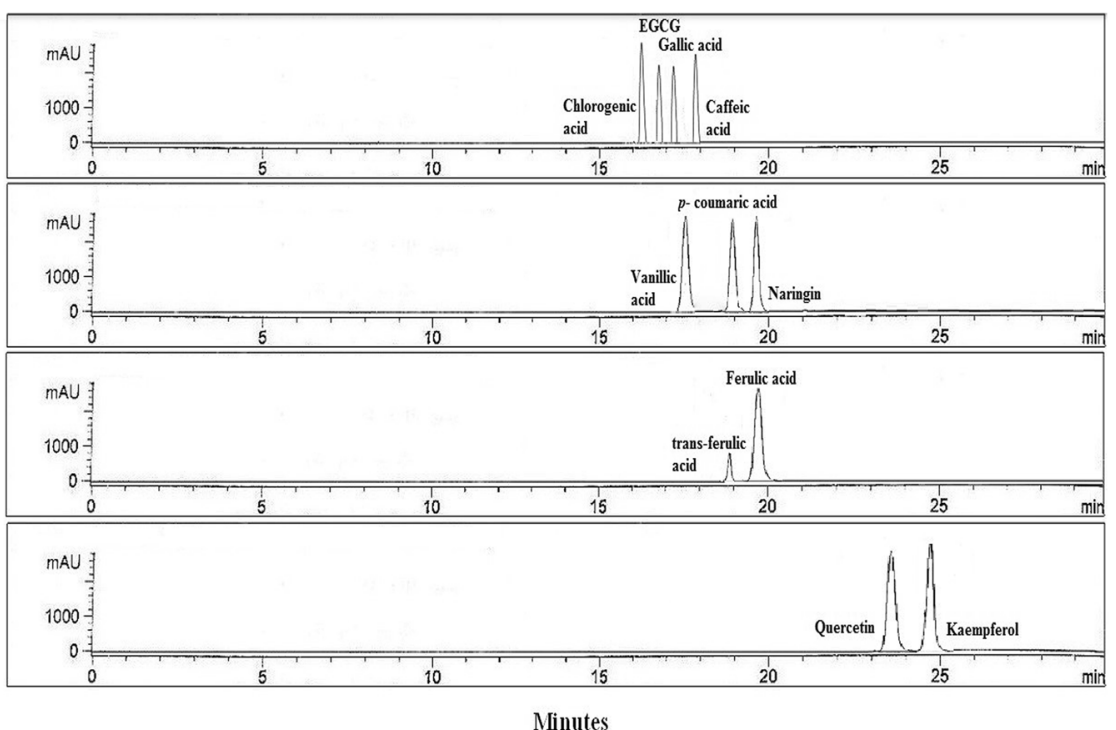

Fig. 5 HPLC chromatogram of the C. betacea extract detected at 254, 280, 329 and $370 \mathrm{~nm}$. Peaks: $1=$ gallic acid; 2 = caffeic acid; $3=$ vanillic acid; $4=p$-coumaric acid; $5=$ naringin; $6=$ trans-ferulic acid; $7=$ ferulic acid; $8=$ kaempferol

mAU
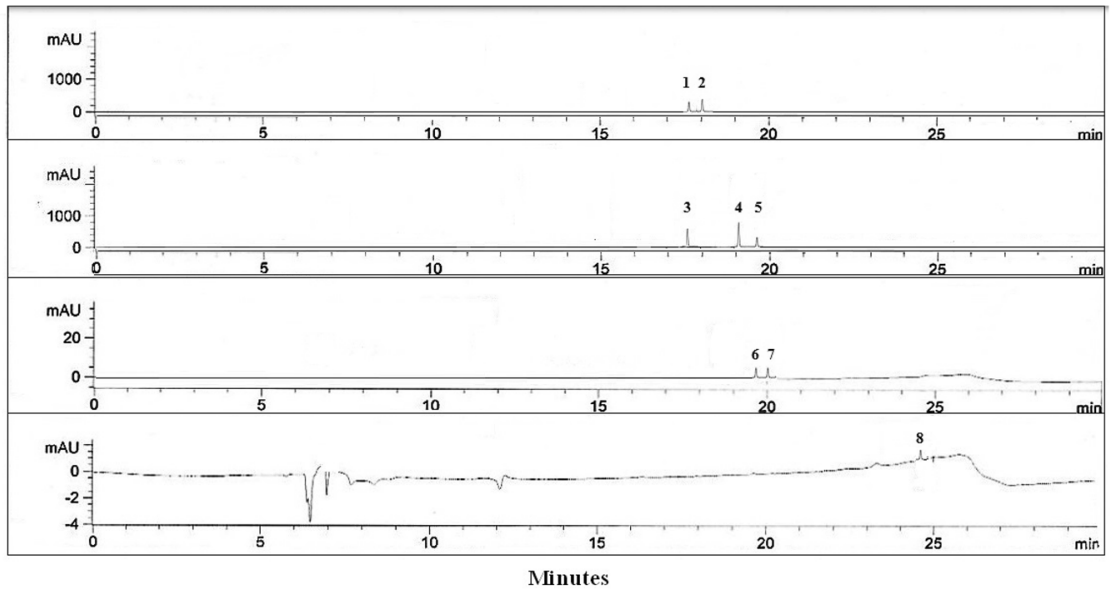

Fig. $6 \mathrm{HPLC}$ chromatogram of the flavonoid and phenolic acid standards at 254, 280, 329 and $370 \mathrm{~nm}$

thiazole was also reported previously to have anticancer properties which suggest the potential of the medicinal activities of tamarillo fruits. It was reported that the hydroxycinnamic acid derivatives is dominant in the peel and pulp of $C$. betacea (Vasco et al. 2009). Noor Atiqah et al. (2014) found that C. betacea contain considerable high mean of total phenolic content $(7.63 \pm 0.37 \mathrm{mg}$ GAE/g). The same study also reported there was also a positive correlation existed between antioxidant activity and total phenolic content of $C$. betacea which suggest that the predominant source of antioxidant potential of C. betacea derives from the polyphenolic compounds present in the fruits. Overall, the 
Table 1 Phenolic acid compositions $\left(\mu \mathrm{g} / \mathrm{g} \mathrm{DW}^{\mathrm{a}}\right)$ of C. betacea

\begin{tabular}{llll}
\hline Samples & $\mathbf{\mu g} / \mathbf{g ~ D W}^{\mathbf{a}}$ & $\mathbf{R T}(\mathbf{m i n})$ & Area (mAU) \\
\hline Ferulic & 0.05 & 19.630 & 31.44 \\
p-coumaric & $0.41 \pm 0.47$ & 19.578 & 38.86 \\
Caffeic & $1.65 \pm 0.72$ & 17.677 & 28.25 \\
Vanillic & $1.11 \pm 1.82$ & 17.682 & 15.99 \\
Trans-ferulic acid & $0.49 \pm 0.51$ & 19.622 & 32.35 \\
Gallic & $3.02 \pm 1.36$ & 17.676 & 26.99 \\
\hline
\end{tabular}

a Dry weight; data are presented in mean \pm S.E.M $(n=3)$; N.D. - not detected

data suggested that $C$. betacea may be a good source of antioxidant compounds in nutraceutical or functional food products.

\section{Flavonoids composition}

Flavonoids are the most diverse group of secondary metabolite that involve in plant growth, reproduction, seed germination and protection against pathogen (Agati et al. 2012). The structural subclass of flavonoids depend on the modifications of the C-ring and they can be divided into; flavonol (quercetin, rutin and kaempferol), flavone (apigenin, luteolin), flavan-3-ol (epicatechin, catechin), anthocyanin (delphinidin and cyaniding), isoflavone (genistein and diazein) and flavanone (hesperetin and naringenin). Flavonoids are the most studied phenolic compounds, due to their biological effects including antioxidant, antimutagenic, anticarcinogenic, and antibacterial properties (Kumar and Pandey 2013). The amount of selected polyphenols (flavonols and flavanones) in C. betacea were reported in Table 2.

\section{Flavonols}

Flavonols compound such as quercetin and kaempferol in C. betacea were examined and shown in Table 2. We detected kaempferol at lower levels with the values of $0.5 \pm 0.80 \mu \mathrm{g} / \mathrm{g}$ DW in C. betacea however, quercetin was not detectable. Tokuşoğlu et al. (2003) reported that kaempferol levels in S. esculentum (tomato) which share the same genus with $C$. betacea were identified in the range between $0.2-0.6 \mu \mathrm{g} / \mathrm{g} \mathrm{FW}$, which were in accordance to our findings. Food derived flavonoids particularly flavonols (kaempferol, quercetin, and myricetin) are reported to exhibit multiple biological functions such as antioxidant, anti-allergenic, anti-inflammatory, cardio-protective and vasodilatory effects. In addition to all these activities, flavonols also has strong anticancer

Table 2 Flavanoids composition $(\mu \mathrm{g} / \mathrm{g} \mathrm{DW}$ ) of the fruits

\begin{tabular}{llll}
\hline Samples & $\boldsymbol{\mu g} / \mathbf{g} \mathbf{D W}^{\mathbf{a}}$ & $\mathbf{R T}(\mathbf{m i n})$ & Area (mAU) \\
\hline Flavonols & & & \\
Quercetin & N.D. & N.D. & N.D. \\
Kaempferol & $0.5 \pm 0.80$ & 24.693 & 13.17 \\
Flavanones & $3.32 \pm 1.50$ & & 37.95 \\
Naringin & 19.582 & \\
\hline
\end{tabular}

${ }^{a}$ Dry weight; data are presented in mean \pm S.E.M $(n=3)$; N.D. - not detected 
activity on several cancer cells such as leukaemia, breast, ovarian, gastric and liver (Joshi et al. 2011).

\section{Flavanones}

Table 2 shows the amount of flavanones (naringin) present in $C$. betacea fruits with the values of $3.32 \pm 1.50 \mu \mathrm{g} / \mathrm{g}$ DW. Flavanones accounted for $90-98 \%$ of flavonoids in citrus fruits such as sweet oranges, lemons, limes and grapefruit (Fowler and Koffas 2009). Flavanones have been demonstrated to induce cytotoxic activity toward various human cancer cell lines with little effect on normal cells. Patil et al. (2009) found that lime juice rich in hesperidin inhibits human pancreatic cancer cell, while Harmon and Patel (2004) reported that the regular intake of flavanones inhibits proliferation of breast cancer cell. This suggests that $C$. betacea fruit with moderate amount of flavanones content making them ideal candidates in developing the potential flavonoid-based chemotherapeutics for anticancer treatment.

\section{Conclusions}

In conclusion, the present study demonstrated that the crude extract of $\mathrm{C}$. betacea possessed antiproliferative activity against HepG2 and MDA-MB-231 cancer cell lines, and more importantly did not exerted an inhibitory effect on the proliferation of the normal cells (3T3). The profiling of phenolic acids and flavonoids by HPLC-DAD-MS has identified some of the major polyphenols that are likely to contribute to the chemopreventive activity. Previous study has found that $C$. betacea exhibited high antioxidant activity largely derived from polyphenolic, flavonols and anthocyanins compounds. It can be concluded from this study that $C$. betacea has a surprisingly wide range of beneficial properties including antioxidant and anticancer properties and has good potential to be further developed in nutraceutical or functional-food products.

\section{Abbreviations}

MTT: 3-(4,5-dimethylthiazol-2yl)-2,5-diphenyltetrazolium bromide); HPLC: high performance liquid chromatography; IC concentration to inhibit cellular proliferation by 50\%; DMSO: dimethyl sulfoxide; HepG2: liver hepatocellular carcinoma; MDA: homo sapiens mammary gland; 3T3: normal mouse fibroblast; $\mathrm{CO}_{2}$ : carbon dioxide; ELISA: enzyme-linked immunosorbent assay; OD: optical density; PBS: phosphate buffered saline; PI: propidium iodide; HPLC-DAD-MS: high-performance liquid chromatography-diode array detection-mass spectrometry; SPSS: statistical package for the social sciences; ANOVA: analysis of variance; AO/PI: acridine orange/propidium iodide; AO: acridine orange; DNA: deoxyribo nucleic acid; GAE: gallic acid equivalent; ROS: reactive oxygen species; FW: fresh weight; DW: dry weight; EGCG: epigallocatechin 3-gallate; SEM: standard error of the mean.

\section{Authors' contributions}

AR, FO and RR made substantial contributions to conception, design, and acquisition of data. MAM contributed for the analysis, interpretation of data and revised the manuscript. FA was reviewed and edited the manuscript. All authors participated in the initial draft of the manuscript. All authors read and approved the final manuscript.

\footnotetext{
Author details

${ }^{1}$ Department of Nutrition and Dietetics, Faculty of Medicine and Health Sciences, Universiti Putra Malaysia (UPM), 43400 Serdang, Selangor, Malaysia. ${ }^{2}$ Haematology Department, University Hospital, Faculty of Medicine and Health Sciences, Sana'a University, Sana'a, Yemen. ${ }^{3}$ Department of Human Anatomy, Faculty of Medicine and Health Sciences, Universiti Putra Malaysia (UPM), 43400 Serdang, Selangor, Malaysia. ${ }^{4}$ Department of Pathology, Faculty of Medicine and Health Sciences, Universiti Putra Malaysia, 43400 Serdang, Selangor, Malaysia.
}

\section{Acknowledgements}

The authors would like to thank all labs'technicians in the cell signalling laboratory. This work was supported by Research Grant from the Universiti Putra Malaysia under Research University Grants (RUGS) (04-02-12-1759RU).

\section{Competing interests}

The authors declare that they have no competing interests. 
Received: 19 April 2016 Accepted: 1 December 2016

Published online: 20 December 2016

\section{References}

Agati G, Azzarello E, Pollastri S, Tattini M (2012) Flavonoids as antioxidants in plants: location and functional significance. Plant Sci 196:67-76

Ali Hassan SH, Abu Bakar MF (2013) Antioxidative and anticholinesterase activity of Cyphomandra betacea fruit. Sci World J 2013:1-7

Barnes S (2003) Phyto-oestrogens and osteoporosis: What is a safe dose? Br J Nutr 89:S101-S108

Bharti AC, Aggarwal BB (2002) Nuclear factor-K B and cancer: its role in prevention and therapy. Biochem Pharmacol 64:883-888

Cos P, Arnold JV, Dirk VB, Louis M (2006) Anti-infective potential of natural products: How to develop a stronger in vitro 'proof of concept'. J Ethnopharmacol 106:290-302

Dai J, Mumper RJ (2010) Plant phenolics: extraction, analysis and their antioxidant and anticancer properties. Molecules 15:7313-7352

de Rosso VV, Mercadante AZ (2007) HPLC-PDA-MS/MS of anthocyanins and carotenoids from dovyalis and tamarillo fruits. J Agric Food Chem 55:9135-9141

Dillard CJ, Bruce GJ (2000) Phytochemicals: nutraceuticals and human health. J Sci Food Agric 80:1744-1756

Dr. Duke's Phytochemical and Ethnobotanical Database (2014) http://www.ars-gov/duke/. Accessed 19 Jan 2015

Ekowati H, Astuti I, Mustofa M (2010) Anticancer activity of Calanone on HeLa cell line. Indonesian J Chem 10:240-244

El-Emam AA, Al-Deeb OA, Al-Omar M, Lehmann J (2004) Synthesis, antimicrobial, and Anti-HIV-1 activity of certain 5-(1-adamantyl)-2-substituted thio-1,3,4-oxadiazoles and 5-(1-adamantyl)-3-substituted aminomethyl-1,3,4-oxadiazoline-2-thiones. Bioorg Med Chem 12:5107-5113

Fantini M, Benvenuto M, Masuelli L, Frajese GV, Tresoldi I, Modesti A, Bei R (2015) In vitro and in vivo antitumoral effects of combinations of polyphenols, or polyphenols and anticancer drugs: perspectives on cancer treatment. Int J Mol Sci 16:9236-9282

Fowler ZL, Koffas MAG (2009) Biosynthesis and biotechnological production of flavanones: current state and perspectives. Appl Microbiol Biot 83:799-808

Ghasemzadeh A, Jaafar HZE, Rahmat A (2010) Antioxidant activities, total phenolics and flavonoids content in two varieties of Malaysia young ginger (Zingiber officinale Roscoe). Molecules 15:4324-4333

Harmon AW, Patel YM (2004) Naringenin inhibits glucose uptake in MCF-7 breast cancer cells: a mechanism for impaired cellular proliferation. Breast Cancer Res Treat 85:103-110

Hounsome N, Hounsome B, Tomos D, Edwards-Jones G (2008) Plant metabolites and nutritional quality of vegetables. J Food Sci 73:R48-R65

Joshi UJ, Gadge AS, D'Mello P, Sinha R, Srivastava V, Govil G (2011) Anti-inflammatory, antioxidant and anticancer activity of quercetin and its analogues. IJRPBS 2:1757-1766

Kaewpiboon C, Winayanuwattikun P, Yongvanich T, Phuwapraisirisan P, Assavalapsakul W (2014) Effect of three fatty acids from the leaf extract of Tiliacora triandra on P-glycoprotein function in multidrug-resistant A549RT-eto cell line. Pharmacogn Mag 10:S549-S556

Kroemer G, Petit P, Zamzami N, Vayssière JL, Mignotte B (1995) The biochemistry of programmed cell death. FASEB J 9:1277-1287

Kumar S, Pandey AK (2013) Chemistry and biological activities of flavonoids: an overview. Sci World J 2013:1-16

Lim TK (2013) Fruits: edible medicinal and non-medicinal plants, vol 6. Springer, New York, pp 326-332

Noor Atiqah AAK, Maisarah AM, Asmah R (2014) Comparison of antioxidant properties of tamarillo (Cyphomandra betacea), cherry tomato (Solanum lycopersicum var. cerasiform) and tomato (Lyopersicon esulentum). Int Food Res J 21:2355-2362

Patil JR, Chidambara Murthy KN, Jayaprakasha GK, Chetti MB, Patil BS (2009) Bioactive compounds from Mexican lime (Citrus aurantifolia) juice induce apoptosis in human pancreatic cells. J Agric Food Chem 57:10933-10942

Sahin K, Kucun O, Sahin N, Sari M (2002) Effects of vitamin C and vitamin E on lipid peroxidation status, some serum hormone, metabolite and mineral concentrations of Japanese quail, reared under heat stress $\left(34^{\circ} \mathrm{C}\right)$. Int J Vitam Nutr Res 72:91-100

Surh YJ (2003) Cancer chemoprevention with dietary phytochemicals. Nat Rev Cancer 3:768-780

Tokuşoğlu O, Unal MK, Yildirim Z (2003) HPLC-UV and GC-MS characterization of the flavonol aglycons quercetin, kaempferol, and myricetin in tomato pastes and other tomato-based products. Acta Chromatogr 13:196-207

Tomás-Barberán FA, Gil MI (eds) (2008) Improving the health-promoting properties of fruit and vegetable products. Woodhead, London

Tsao R (2010) Chemistry and biochemistry of dietary polyphenols. Nutrients 2:1231-1246

Uddin R, Saha MR, Subhan N, Hossain H, Jahan IA, Akter R, Alam A (2014) HPLC-analysis of polyphenolic compounds in Gardenia jasminoides and determination of antioxidant activity by using free radical scavenging assays. Adv Pharm Bull 4:273-281

Vasco C, Avila J, Ruales J, Svanberg U, Kamal-eldin A (2009) Physical and chemical characteristics of golden-yellow and purple-red varieties of tamarillo fruit (Solanum betaceum Cav.). Int J of Food Sci Nutr 60:278-288

Wattenberg LW (1985) Chemoprevention of cancer. Cancer Res 45:1-8 